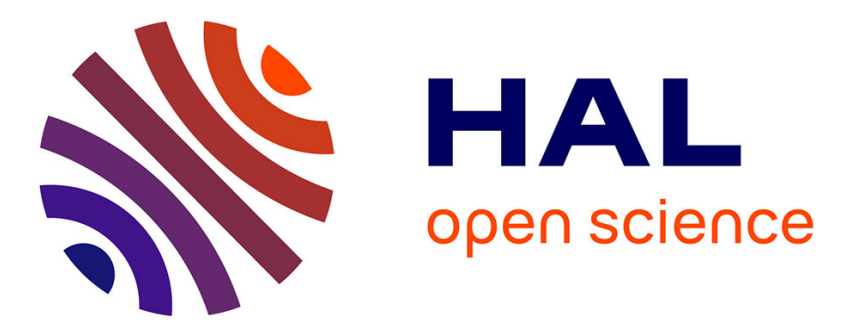

\title{
Comparison of three different diets for organic broilers: effects on performance and body condition
}

Bas Rodenburg, Jan van Harn, Marinus Krimpen, Marko Ruis, Izak Vermeij, Hans Spoolder

\section{> To cite this version:}

Bas Rodenburg, Jan van Harn, Marinus Krimpen, Marko Ruis, Izak Vermeij, et al.. Comparison of three different diets for organic broilers: effects on performance and body condition. British Poultry Science, 2008, 49 (01), pp.74-80. 10.1080/00071660701823085 . hal-00545325

\section{HAL Id: hal-00545325 https://hal.science/hal-00545325}

Submitted on 10 Dec 2010

HAL is a multi-disciplinary open access archive for the deposit and dissemination of scientific research documents, whether they are published or not. The documents may come from teaching and research institutions in France or abroad, or from public or private research centers.
L'archive ouverte pluridisciplinaire HAL, est destinée au dépôt et à la diffusion de documents scientifiques de niveau recherche, publiés ou non, émanant des établissements d'enseignement et de recherche français ou étrangers, des laboratoires publics ou privés. 


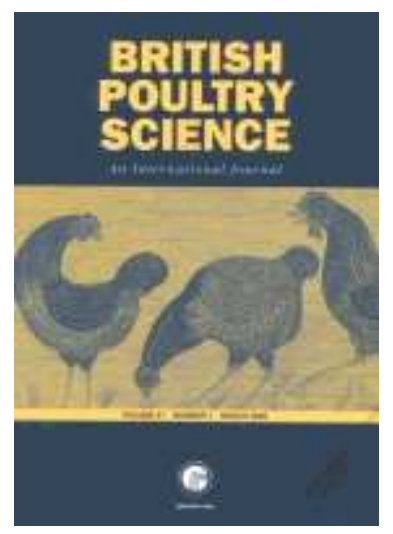

\section{Comparison of three different diets for organic broilers: effects on performance and body condition}

\begin{tabular}{|r|l|}
\hline Journal: & British Poultry Science \\
\hline Manuscript ID: & CBPS-2007-085.R1 \\
\hline Manuscript Type: & Original Manuscript \\
\hline Dute Submitted by the & 27-Aug-2007 \\
\hline Complete List of Authors: & $\begin{array}{l}\text { Rodenburg, Bas; Wageningen University, Animal Breeding and } \\
\text { Genomics Centre } \\
\text { van Harn, Jan; Wageningen University and Research Centre, Animal } \\
\text { Sciences Group } \\
\text { Krimpen, Marinus; Wageningen University and Research Centre, } \\
\text { Animal Sciences Group } \\
\text { Ruis, Marko; Wageningen University and Research Centre, Animal } \\
\text { Sciences Group } \\
\text { Vermeij, Izak; Wageningen University and Research Centre, Animal } \\
\text { Sciences Group } \\
\text { Spoolder, Hans; Wageningen University and Research Centre, } \\
\text { Animal Sciences Group }\end{array}$ \\
\hline Keywords: & Broilers, Diet, Free range, Welfare, Growth \\
\hline
\end{tabular}

\section{S) ScholaroNE \\ Manuscript Central}


CBPS-2007-085

ed. MacLeod, November 2007

3 Comparison of three different diets for organic broilers: effects on performance and body

4 condition

5

6 T.B. RODENBURG ${ }^{*}$, J. VAN HARN, M.M. VAN KRIMPEN, M.A.W. RUIS, I. VERMEIJ

7 AND H.A.M. SPOOLDER

8

9 Animal Sciences Group - Animal Production, Wageningen UR, P.O. Box 65,

108200 AB Lelystad, The Netherlands

11

12

RUNNING TITLE: PERFORMANCE OF ORGANIC BROILERS

14

15

16

17

18 *To whom correspondence should be addressed: Animal Breeding and Genomics Centre,

19 Wageningen University, P.O. Box 338, 6700 AH Wageningen, The Netherlands

20 Telephone: $\quad+31317483936$

$21 \quad$ Fax: $\quad+31317483929$

$22 \quad$ E-mail: $\quad$ bas.rodenburg@wur.nl

Accepted for publication $7^{\text {th }}$ November 2007 
23 Abstract 1. The aim of this study was to assess the feasibility of $100 \%$ organic feed for

24 organic broilers by comparing it with $80 \%$ organic feed (situation at the time of the 25 experiment; 2004) and 95\% organic feed (alternative).

26 2. Diets were optimised for nutritional value, allowing a maximum $10 \%$ increase in feed

27 price when using $100 \%$ organic feedstuffs. This could only be achieved at the expense of the 28 methionine content.

29 3. The birds were reared from zero to three weeks of age in a broiler house in three groups of 30500 broilers each on either an 80 , a 95, or a $100 \%$ organic starter diet. At three weeks of age, 31 they were transferred to 15 pens with an outdoor run. Each treatment group of 500 birds was 32 divided into 5 groups of 95 and given an 80, a 95, or a $100 \%$ organic finisher diet.

33 4. Broilers receiving $100 \%$ organic feed reached a lower body weight and grew more slowly 34 than those receiving $95 \%$ organic feed, mainly because of a lower feed intake.

35 5. Broilers on 95 or $100 \%$ organic feed had a higher incidence of breast blisters than broilers 36 receiving $80 \%$ organic feed.

37 6. The cost price for meat from broilers that received $80 \%$ organic feed was $€ 1.83$ per $\mathrm{kg}$ 38 live weight. The cost prices for broilers that received 95 and $100 \%$ organic feed were $€ 1.84$ $39(+0.8 \%)$ and $€ 1.93(+5.4 \%)$ per kg live weight respectively.

40 7. In conclusion, $95 \%$ organic feed led to a better performance than $100 \%$ organic feed in 41 this study. Probably, the lower methionine content in the $100 \%$ organic feed negatively 42 affected performance. The results for $95 \%$ organic feed were similar to $80 \%$ organic feed, 43 except for a higher incidence of breast blisters.

\section{INTRODUCTION}

45 In organic animal husbandry, the feed must be produced from organic feedstuffs 46 according to EU Council Directive 1804/1999. Until 2012, limited use of 47 conventional feedstuffs is permitted, if there are too few organic feedstuffs available. 48 After December 2011, all feed used in organic animal production should be produced 49 from $100 \%$ organic feedstuffs. At present $85 \%$ organic feed is commonly used in 
50 organic broiler production. The transition from $85 \%$ to $100 \%$ organic feed can cause

51 problems in poultry. The supply of protein and amino acids (especially methionine)

52 is the most common problem, because some feedstuffs are not available from organic

53 origin and because organic feedstuffs generally have lower protein contents than

54 conventional feedstuffs (Hovi and Sundrum, 2001; Zollitsch and Baumung, 2004).

55 Furthermore, addition of synthetic methionine is not an option, as this is prohibited in

56 organic farming (EU 1804/1999). It is possible to avoid shortage of methionine in

$57100 \%$ organic feed by addition of specific organic feedstuffs, such as organic sesame

58 seed expeller. The problem is that these feedstuffs are not generally available and are

59 relatively expensive. Rose et al. (2004) compared 100\% organic diets with low and

60 high methionine levels and found that laying hens fed on the high methionine diet

61 performed better than hens given the low methionine diet. The higher ingredient

62 costs of the high methionine diet, however, resulted in a $50 \%$ reduction of the margin

63 of egg income over feed costs.

64 In organic broilers, problems of $100 \%$ organic feed may be reduced because a

65 slow growing broiler, which has lower nutrient requirements than fast growing

66 broilers, is used for organic production (Zollitsch and Baumung, 2004). On the other

67 hand, imbalance of protein in the feed can lead to an increased water intake and wet

68 manure (Walker and Gordon, 2001). Wet manure can cause other problems, such as

69 a poor litter quality and a poor body condition (Weaver and Meijerhof, 1991). As

70 organic broilers have an outdoor run, it may be that they can partly compensate for

71 imbalances in the feed by foraging in the outdoor run, consuming vegetation, worms,

72 and insects (Hermansen et al., 2004). Alternatives for $100 \%$ organic feed could be

$7395 \%$ organic feed or $100 \%$ organic feed with synthetic amino acids (Lemme et al.,

74 2005; Moritz et al., 2005). 
The aim of the present study was to compare three different diets for organic

76 broilers: $80 \%$ organic feed (situation at the time of the experiment; 2004), 95\%

77 organic feed (alternative) and 100\% organic feed. It was hypothesised that broilers

78 that received $80 \%$ organic feed would have a better performance and a better body

79 condition than broilers that received $100 \%$ organic feed (due to the lower methionine

80 concentration), and that broilers receiving 95\% organic feed would be intermediate.

81 Also, broilers that received $100 \%$ organic feed were expected to compensate for

82 possible deficiencies in the feed by increased use of the outdoor run.

MATERIALS AND METHODS

\section{$84 \quad$ Feed}

85 A total of 6 feed formulations were used: starter (0-3 weeks) and finisher (3-11

86 weeks) feeds, each with 80,95 , or $100 \%$ organic feedstuffs. The feed was produced

87 by van Gorp-Teurlings BV, Waspik, The Netherlands. In 95 and $100 \%$ organic

88 feeds, conventional sesame-seed expeller and toasted soybeans were removed,

89 compared with the $80 \%$ organic feed (Table 1). Additionally, in $100 \%$ organic feed,

90 conventional maize gluten meal and potato protein were removed, compared with the

9180 and the $95 \%$ organic feed. The $80 \%$ and $95 \%$ organic feeds were mainly

92 supplemented with organic soya bean meal.

Tables 1 and 2 near here

93 The feed manufacturer was asked to produce 80,95 , and $100 \%$ organic diets

94 from feedstuffs that are generally available and also to avoid feedstuffs or additives

95 that would make the feed too costly, allowing a maximum $10 \%$ increase in feed price

96 when using 100\% organic feedstuffs. Within these restrictions, it proved impossible

97 to keep the content of digestible methionine the same in all diets. Methionine

98 concentration decreased as the amount of organic feedstuffs increased (Table 2).

$99 \quad$ Rearing 
100 Rearing of the broilers took place in June 2004. Three groups of 500 slow growing 101 broilers (Hubbard JA 957) were housed in three compartments of a climate102 controlled broiler house as d-old chicks. JA 957 chicks were used because this is the 103 hybrid that is generally used for organic broiler production in The Netherlands. Each

104 compartment measured $4.2 \times 6.8 \mathrm{~m}$ with an available floor space of $28.1 \mathrm{~m}^{2}$. Each 105 compartment was fitted with 7 feeders (MiniMax, Roxell) and 45 nipple drinkers 106 (Avron). The broilers were housed on softwood shavings and had ad libitum access 107 to feed and water. One group received an $80 \%$, one group a $95 \%$ and one group a $108100 \%$ organic starter diet. During the first $2 \mathrm{~d}$, continuous light was used. Thereafter, 109 an 18L:6D lighting schedule was used.

\section{Experimental design}

111 The experiment was conducted in July and August 2004. At three weeks of age, the 112 broilers were transferred to 15 pens with an outdoor run. Each pen measured $5.3 \mathrm{x}$ $1132.2 \mathrm{~m}$ with an available floor space of $11.4 \mathrm{~m}^{2}$. The pens were all located next to 114 each other. Each treatment group of 500 broilers was divided into 5 groups of 95 115 broilers, resulting in a total of 15 experimental groups. The remainder of the broilers 116 were excluded from the experiment. The 15 pens that were used from 3-11 weeks of 117 age had an open front that was covered only with windbreak netting. The broilers 118 were housed on softwood shavings and had ad libitum access to feed and water. Five 119 groups received an $80 \%, 5$ groups a $95 \%$ and 5 groups a $100 \%$ organic finisher diet. 120 For each group, treatment during the experimental period was the same as treatment 121 during the rearing period $(80 \%, 95 \%$ or $100 \%$ organic feed $)$. The treatments were 122 allocated to the pens at random. During the experimental period, no extra light was 123 given (daylight only). Temperature and humidity in the pens were recorded 124 continuously using the uMETOS, manufactured by Pessl, Germany. After one week 
125 of habituation to the new pens, the broilers had permanent $24 \mathrm{~h}$ access to the outdoor

126 run (approximately $7 \mathrm{~m}^{2}$ per bird). The windbreak netting was pulled up $50 \mathrm{~cm}$ to

127 allow the broilers access to the outdoor run over the full width of the pen. The

128 outdoor run consisted of a concrete part near the house $\left(11.4 \mathrm{~m}^{2}\right.$ per group) and a

129 large part with long grass and other vegetation $\left(640 \mathrm{~m}^{2}\right.$ per group). In the pen, the

130 broilers were kept at a stocking density of $8 \mathrm{birds} / \mathrm{m}^{2}$. The broilers were slaughtered

131 at 11 weeks of age.

\section{Observations}

133 Performance (body weight gain, feed intake, feed conversion ratio and mortality),

134 use of the outdoor run, litter quality, gait score, body condition, and slaughter data

135 were recorded. To evaluate performance, all broilers were weighed at $0,3,7$, and 11

136 weeks of age. Feed intake per group and mortality were recorded daily. To study the

137 use of the outdoor run from 5 - 9 weeks of age, every Wednesday morning at $0830 \mathrm{~h}$

138 the number of broilers on the concrete part and on the grass of the outdoor run was

139 counted. Litter samples were taken at 5, 7, 9, and 11 weeks of age from each pen to

140 analyse the dry matter content of the litter, using a pooled sample from 5 locations in

141 the pen. At 10 weeks of age, the gait of all broilers was assessed, using a group

142 scoring method modified from the method described by Kestin et al. (1992). The gait

143 score had a 6-point scale from 0 to 5 , where $0=$ no observable locomotory problems

144 and $5=$ unable to walk. In each pen, the percentage of broilers in each of the 6 gait

145 score categories was recorded. At 10 weeks of age, the body condition of the broilers

146 was recorded as well. The incidence and extent of breast smearing, breast irritations,

147 scratches on the thighs, hockburns and footpad irritations were determined with a

148 visual scoring method. The visual scoring method had a 4 point scale from 0 to 3 ,

149 where $0=$ no visual signs and $3=$ severe visual abnormalities. At slaughter, the 
150 processing yields of 10 males and 10 females per pen were recorded. These broilers

151 were randomly selected and processed at a commercial processing plant. According

152 to a standard procedure, carcase yield, and yields of wings, breast meat, back and

153 legs were determined. The carcase yield was calculated by dividing the carcase

154 weight by the total body weight. The leg, wing, breast, and back yield were

155 calculated by dividing their weight by the carcase weight. Finally, data of the

156 experiment were used for an economic evaluation. Only significant differences and

157 tendencies for differences in performance between treatments were taken into

158 account for this evaluation. Other starting-points were taken from Vermeij (2004).

159 Feed prices were supplied by the feed manufacturer.

160 Statistical analysis

161 Data were analysed in GenStat using analysis of variance, with the factor feed. Pen 162 was the experimental unit. The Bonferroni test was used to test for significant 163 differences between treatments in case of an overall effect of feed. Use of the 164 outdoor run and dry matter content of the litter were analysed using repeated 165 measures analysis of variance, to analyse the effect of age.

\section{RESULTS}

\section{General}

168 During the outdoor phase, temperature varied strongly between day and night; the 169 lowest temperature recorded was $8^{\circ} \mathrm{C}$ and the highest temperature was $32^{\circ} \mathrm{C}$. The 170 mean temperature was $19^{\circ} \mathrm{C}$. Air humidity was between 38 and $100 \%$ with a mean of $17186 \%$. During the outdoor phase (from 4 weeks of age) there was some mortality due 172 to predators, especially birds of prey. The mortality due to predation was distributed 173 equally over the treatments.

\section{Performance}


175 At the end of the rearing period at three weeks of age, broilers that had received $95 \%$

176 organic feed were numerically heavier than broilers from the other two treatments

177 (Table 3; not tested for significance due to limited number of groups during rearing).

178 Over the entire growing period, broilers that received $100 \%$ organic feed reached a

179 lower body weight $\left(F_{2,12}=4.49, P<0.05\right)$ and grew more slowly $\left(F_{2,12}=4.37, P<\right.$

180 0.05) than broilers that received $95 \%$ organic feed. There were no differences in

181 growth between broilers receiving $80 \%$ organic feed and broilers from the other

182 treatments. There also were no differences in mortality between the treatments. Feed

183 intake was lower in pens with $100 \%$ organic feed than in pens with 80 and $95 \%$

184 organic feed $\left(F_{2,12}=17.89, P<0.001\right)$. There was no difference in feed conversion,

185 as calculated in practice (uncorrected for mortality). After correction for mortality,

186 feed conversion tended to be better in pens that received $95 \%$ and $100 \%$ organic feed

187 compared with pens that received $80 \%$ organic feed $\left(F_{2,12}=2.89, P<0.10\right)$. Table 3

188 Use of the outdoor run

and

Figure

189 During observations of use of the outdoor run, a mean of $9 \%$ of all the broilers was

190 observed on the concrete part of the outdoor run, near the house, and $7 \%$ of the

191 broilers on the grass (Figure). The broilers were mainly observed in the part of the

192 outdoor run located closest to the pens. There were no differences in use of the

193 outdoor run between treatments. Use of the outdoor run increased with age $\left(F_{4,48}=\right.$

$194 \quad 5.55, P<0.01)$.

195 Litter quality

196 Dry matter content of the litter was lower in pens that received $100 \%$ organic feed 197 than in pens that received $95 \%$ or $80 \%$ organic feed at 7 weeks of age $\left(F_{2,12}=38.70\right.$, $198 P<0.001 ;$ Table 4). At 5, 9, and 11 weeks of age, there were no significant 
199 differences between the treatments. Dry matter content of the litter increased from 5

200 to 11 weeks of age $\left(F_{3,35}=121.81, P<0.001\right)$.

201 Gait score

202 About $70 \%$ of all the broilers had no gait abnormalities. $25 \%$ of the broilers had a 203 slightly trembling gait and 5\% of the broilers had a trembling gait. There were no

204 differences in gait score between treatments.

Tables 4 \& 5 near here

\section{Body condition}

206 Broilers that received 95 or $100 \%$ organic feed had a higher incidence of breast

207 blisters than broilers receiving $80 \%$ organic feed $\left(F_{2,12}=3.95, P<0.05\right.$; Table 5).

208 Furthermore, broilers that received $100 \%$ organic feed tended to have more footpad

209 irritations than broilers that received 95\% organic feed $\left(F_{2,12}=3.26, P<0.10\right)$. There

210 were no differences in breast smearing, breast irritations, and hock irritations

211 between the treatments.

\section{Processing yields}

213 Broilers that received a $100 \%$ organic feed had a higher wing yield $\left(F_{2,12}=4.39, P<\right.$

$2140.05)$ and tended to have a higher leg yield $\left(F_{2,12}=3.05, P<0.10\right)$ than broilers

215 receiving 80 or $95 \%$ organic feed (Table 6). There were no significant differences in

216 breast yield between treatments.

Tables 6 \& 7 near here

\section{Economic evaluation}

218 Feed prices for $95 \%$ and $100 \%$ organic feed were $4.6 \%$ and $7.6 \%$ higher compared

219 with $80 \%$ organic feed. The cost price for broilers that received an $80 \%$ organic feed

220 was $€ 1.83$ per $\mathrm{kg}$ live weight. The cost prices per $\mathrm{kg}$ live weight for broilers that

221 received a $95 \%$ and $100 \%$ organic feed were $€ 1.84(+0.8 \%)$ and $€ 1.93(+5.4 \%)$

222 respectively. 
224 Broilers that received 100\% organic feed reached a lower body weight and grew 225 more slowly than broilers that received 95\% organic feed. Possibly, the methionine 226 level of the $100 \%$ organic feed was too low, resulting in an imbalance in amino acid 227 profile. Moran (1994) also found that broilers on a low methionine diet grew slower 228 than broilers from a control group, especially during the first six weeks of life. It may 229 also be possible that the $100 \%$ organic feed used in the present study had a lower 230 palatability than 80 and $95 \%$ organic feed, as the feed intake of broilers that received $231 \quad 100 \%$ organic feed was lower as well.

There were no differences in use of the outdoor run in this study and the use 233 was lower than in other studies, with a mean of about $15 \%$. For instance, Christensen 234 et al. (2003) found a mean use of the outdoor run of about $35 \%$. The lower use of the 235 outdoor run may be caused by the type of housing (open front), but it may also be 236 that counting once a week was too limited to get a good impression of use of the 237 outdoor run. Nielsen et al. (2003) did find an effect of type of feed on use of the 238 outdoor run in free range broilers. In their study broilers that received a moderate 239 energy feed made more use of the outdoor run than broilers that received a low 240 energy feed. Similarly, Moritz et al. (2005) showed that broilers that received lower 241 methionine levels in their feed spent more time foraging, especially if their feed 242 intake was restricted.

243 Broilers that received 95 or $100 \%$ organic feed had more breast blisters than 244 broilers that received $80 \%$ organic feed. This difference could be caused by a poorer 245 litter quality or by a lower activity of the broilers. In the pens that received $100 \%$ 246 organic feed the dry matter content of the litter was indeed lower than in the pens 247 that received $80 \%$ organic feed (significant only in week 7), but this was not the case 248 in the pens that received 95\% organic feed. Perhaps, broilers that received $95 \%$ 
249 organic feed were less active than broilers that received $80 \%$ organic feed, but 250 activity was not recorded in this study. The wetter litter in the pens that received $251100 \%$ organic feed may have been caused by an imbalance of the amino acid profile 252 in the feed. This can lead to an increased water intake and wet manure (Walker and 253 Gordon, 2001). Contrary to expectations, the dry matter content of the litter was 254 lowest at 5 weeks of age and increased to the end of the growing period. This may be 255 caused by the access to the outdoor run from 5 weeks of age and by weather 256 influences. In comparison with other studies with slow growing broilers kept until 56 257 days of age (van Horne et al., 2004), there was a higher incidence of gait 258 abnormalities in this study, probably due to the longer growing period.

$259 \quad$ Feed prices for $95 \%$ and $100 \%$ organic feed were higher compared with $80 \%$ 260 organic feed. The cost price for meat from broilers that received $95 \%$ organic feed 261 was slightly higher than the cost price for meat from broilers that received $80 \%$ 262 organic feed $(+0.8 \%)$. For meat from broilers that received $100 \%$ organic feed, the 263 cost price was $5.4 \%$ higher. The smaller increase in costs for the meat from broilers 264 that received $95 \%$ organic feed was due to the fact that the improvements in feed 265 conversion ratio and live weight compensated for the higher feed costs.

266 In conclusion, 95\% organic feed led to a better performance than $100 \%$ 267 organic feed in this study. Probably, the lower methionine content in the $100 \%$ 268 organic feed negatively affected performance. The results for $95 \%$ organic feed were 269 similar to $80 \%$ organic feed, except for a higher incidence of breast blisters.

\section{ACKNOWLEDGEMENTS}

271 The authors would like to thank Eveline Coenen for her help with the experimental

272 work. We would also like to thank the employees of van Gorp Diervoeders BV, 273 Waalwijk, The Netherlands, for their help with formulating and producing the feed 
274 and the animal care staff of experimental farm 'Het Spelderholt', Lelystad, The

275 Netherlands, for taking good care of the broilers. This project was funded by the

276 Dutch Ministry of Agriculture, Nature Conservation and Food Quality (LNV).

\section{REFERENCES}

278 CHRISTENSEN, J.W., NIELSEN, B.L., YOUNG, J.F. \& NODDEGAARD, F. (2003)

279 Effects of calcium deficiency in broilers on the use of outdoor areas, foraging

280 activity and production parameters. Applied Animal Behaviour Science, 82: 229-240.

281 HERMANSEN, J.E., STRUDSHOLM, K. \& HORSTED, K. (2004) Integration of organic

282 animal production into land use with special reference to swine and poultry.

283 Livestock Production Science, 90: 11-26.

284 HOVI, M. \& SUNDRUM, A. (2001) Feeding for health and welfare. The 4th NAHWOA

285 Workshop, Wageningen, The Netherlands, pp. 198-202.

286 KESTIN, S.C., KNOWLES, T.G., TINCH, A.E. \& GREGORY, N.G. (1992) Prevalence of

287 leg weakness in broiler chickens and its relationship with genotype. The Veterinary

288 Record, 131: 190-194.

289 LEMME, A., DAMME, K. \& PETRI, A. (2005) Effect of DL-methionine on various

290 performance and slaughter characteristics in slowly growing broilers fed according

291 to organic farming recommendations. Archiv fur Geflugelkunde, 69: 159-166.

292 MORAN, E.T. (1994) Response Of Broiler Strains Differing In Body-Fat To Inadequate

293 Methionine - Live Performance And Processing Yields. Poultry Science, 73: 1116-

$294 \quad 1126$.

295 MORITZ, J.S., PARSONS, A.S., BUCHANAN, N.P., BAKER, N.J., JACZYNSKI, J.,

296 GEKARA, O.J. \& BRYAN, W.B. (2005) Synthetic methionine and feed restriction

297 effects on performance and meat quality of organically reared broiler chickens.

$298 \quad$ Journal of Applied Poultry Research, 14: 521-535. 
NIELSEN, B.L., THOMSEN, M.G., SORENSEN, P. \& YOUNG, J.F. (2003) Feed and strain effects on the use of outdoor areas by broilers. British Poultry Science, $\mathbf{4 4}$ : 161-169.

ROSE, S.P., CRAIG, L. \& PRITCHARD, S. (2004) A comparison of organic laying hen feed formulations. British Poultry Science, 45: S63-S64.

VAN HORNE, P.L.M., VAN HARN, J.J. \& RODENBURG, T.B. (2004) Slower growing broilers: performance, mortality and welfare. XXII World's Poulty Congress Abstract Book, Istanbul, Turkey, pp. 326.

VERMEIJ, I., 2004. Production costs of organic broiler meat (in Dutch). In: Internal report, pp. 19: Animal Sciences Group, Wageningen UR.

WALKER, A. \& GORDON, S. (2001) Nutritional issues in organic poultry systems. Proceedings of the 4th NAHWOA Workshop, Wageningen, The Netherlands, pp. 192-197.

WEAVER, W.D. \& MEIJERHOF, R. (1991) The effect of different levels of relative humidity and air movement on litter conditions, ammonia levels, growth, and carcass quality for broiler chickens. Poultry Science, 70: 746-755.

ZOLLITSCH, W. \& BAUMUNG, R. (2004) Protein supply for organic poultry: options and shortcomings. Organic livestock farming: potential and limitations of husbandry practice to secure animal health and welfare and food quality - Proceedings of the 2nd SAFO Workshop, Witzenhausen, Germany, pp. 153-159. 
320 Table 1. Feed composition of $80 \%$, 95\% and $100 \%$ organic starter (0-4 weeks) and finisher feeds as $\mathrm{g} / \mathrm{kg}$ of total Starter diets (0-3 weeks) Finisher diets (3-11 weeks)

\begin{tabular}{|c|c|c|c|c|c|c|}
\hline & \multicolumn{3}{|c|}{ Starter diets (0-3 weeks) } & \multicolumn{3}{|c|}{ Finisher diets (3-11 weeks) } \\
\hline & $80 \%$ & $95 \%$ & $100 \%$ & $80 \%$ & $95 \%$ & $100 \%$ \\
\hline Maize organic & 200 & 200 & 200 & 130 & 190 & 150 \\
\hline Wheat organic & 390 & 430 & 370 & 450 & 465 & 435 \\
\hline Sunflower organic & 40 & 60 & 70 & 80 & 70 & 70 \\
\hline Pea organic & 30 & & & 80 & 50 & 40 \\
\hline Rapeseed organic & 30 & 40 & 50 & & 20 & 20 \\
\hline Soya bean meal organic & 70 & 160 & 240 & 25 & 100 & 220 \\
\hline Sesame organic & & 10 & 10 & & 10 & 10 \\
\hline Soja oil organic & 5 & 15 & 25 & 5 & 15 & 25 \\
\hline Premix, Minerals and Vitamins & 30 & 30 & 30 & 30 & 30 & 30 \\
\hline Maize gluten & 20 & 10 & & 40 & 10 & \\
\hline Potato protein & 50 & 40 & & 25 & 40 & \\
\hline Soybeans toasted & 55 & & & 110 & & \\
\hline Sesame seed expeller & 50 & & & 25 & & \\
\hline Yeast & 25 & & & & & \\
\hline Organic acid & 5 & 5 & 5 & & & \\
\hline
\end{tabular}


Table 2. Calculated feed composition of $80 \%, 95 \%$ and $100 \%$ organic starter (0-4 weeks)

and finisher feeds

\begin{tabular}{|c|c|c|c|c|c|c|c|}
\hline & \multirow[t]{2}{*}{ Unit } & \multicolumn{3}{|c|}{ Starter diets (0-4 weeks) } & \multicolumn{3}{|c|}{ Finisher diets (4-12 weeks) } \\
\hline & & $80 \%$ & $95 \%$ & $100 \%$ & $80 \%$ & $95 \%$ & $100 \%$ \\
\hline $\mathrm{CP}$ & $\mathrm{g} / \mathrm{kg}$ & 220 & 207 & 205 & 194 & 185 & 197 \\
\hline Crude fat & $\mathrm{g} / \mathrm{kg}$ & 55 & 58 & 74 & 60 & 50 & 68 \\
\hline Crude fibre & $\mathrm{g} / \mathrm{kg}$ & 39 & 44 & 50 & 49 & 45 & 50 \\
\hline Crude ash & $\mathrm{g} / \mathrm{kg}$ & 61 & 60 & 63 & 59 & 57 & 61 \\
\hline ME broiler & $\mathrm{MJ} / \mathrm{kg}$ & 11.4 & 11.4 & 11.4 & 11.5 & 11.5 & 11.4 \\
\hline Lysine $^{1}$ & $\mathrm{~g} / \mathrm{kg}$ & 10.7 & 10 & 9.8 & 8.85 & 8.8 & 9.4 \\
\hline Methionine $^{1}$ & $\mathrm{~g} / \mathrm{kg}$ & 4.3 & 3.7 & 3.4 & 3.5 & 3.35 & 3.2 \\
\hline Methionine+Cysteïne $^{1}$ & $\mathrm{~g} / \mathrm{kg}$ & 8.3 & 7.5 & 7.1 & 7.1 & 6.8 & 6.75 \\
\hline Threonine $^{1}$ & $\mathrm{~g} / \mathrm{kg}$ & 8.9 & 8 & 7.5 & 7.3 & 7.2 & 7.1 \\
\hline Tryptophan $^{1}$ & $\mathrm{~g} / \mathrm{kg}$ & 2.6 & 2.5 & 2.5 & 2.2 & 2.2 & 2.4 \\
\hline Calcium & $\mathrm{g} / \mathrm{kg}$ & 9.5 & 9.5 & 9.5 & 10 & 9.5 & 9.5 \\
\hline Phosphorus & $\mathrm{g} / \mathrm{kg}$ & 6.9 & 7 & 7.2 & 6.1 & 6.1 & 6.3 \\
\hline Available Phosphorus ${ }^{2}$ & $\mathrm{~g} / \mathrm{kg}$ & 3.7 & 3.7 & 3.7 & 3.1 & 3.1 & 3.1 \\
\hline Linoleic acid & $\mathrm{g} / \mathrm{kg}$ & 21 & 20 & 26 & 26.5 & 18 & 23.5 \\
\hline
\end{tabular}

${ }^{1}$ Total amount.

$326{ }^{2}$ available phosphorus $=$ total phosphorus - phytate phosphorus. 
Table 3. Performance of broilers receiving $80 \%, 95 \%$ and $100 \%$ organic feed

328

$(0-11$ weeks $)$

\begin{tabular}{lccc}
\hline & $80 \%$ & $95 \%$ & $100 \%$ \\
\hline Body weight 1 day (g) & 42 & 42 & 41 \\
Body weight 3 weeks (g) & 493 & 561 & 499 \\
Body weight 11 weeks (g) & $3051^{\mathrm{ab}}$ & $3094^{\mathrm{a}}$ & $2970^{\mathrm{b}}$ \\
Growth (g/d) & $41.2^{\mathrm{ab}}$ & $41.8^{\mathrm{a}}$ & $40.1^{\mathrm{b}}$ \\
Mortality (\%) & 3.3 & 3.5 & 2.9 \\
Feed conversion & $2.65^{(\mathrm{a})}$ & $2.59^{(\mathrm{b})}$ & $2.58^{(\mathrm{b})}$ \\
Total feed intake (g) & $7958^{\mathrm{a}}$ & $7900^{\mathrm{a}}$ & $7544^{\mathrm{b}}$ \\
Daily feed intake (g/day) & $109.0^{\mathrm{a}}$ & $108.2^{\mathrm{a}}$ & $103.3^{\mathrm{b}}$ \\
Feed conversion (practice) & 2.63 & 2.58 & 2.64
\end{tabular}

329

${ }^{\mathrm{ab}}$ Values in a row not sharing a common superscript are significantly different $(P<0.05)$.

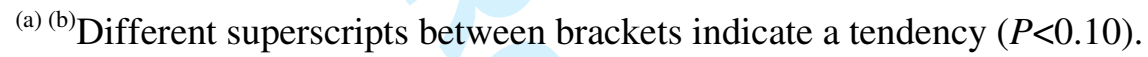


331 Table 4. Dry matter content (\%) of the litter of broilers receiving $80 \%$, 95\% and $100 \%$ 332 organic feed from 5 - 11 weeks of age

\begin{tabular}{lccc}
\hline Age (weeks) & $80 \%$ & $95 \%$ & $100 \%$ \\
\hline 5 & 63 & 63 & 56 \\
7 & $70^{\mathrm{a}}$ & $73^{\mathrm{a}}$ & $61^{\mathrm{b}}$ \\
9 & 72 & 76 & 73 \\
11 & 77 & 79 & 77
\end{tabular}

$333{ }^{\mathrm{ab}}$ Values in a row not sharing a common superscript are significantly different $(P<0.05)$. 
334 Table 5. Body condition of broilers receiving $80 \%$, 95\% and 100\% organic feed at 10 weeks

\begin{tabular}{|c|c|c|c|}
\hline & $80 \%$ & $95 \%$ & $100 \%$ \\
\hline Breast smearing: none & 1.5 & 1.5 & 3.0 \\
\hline slight & 79.5 & 85.5 & 84.0 \\
\hline moderate & 19.0 & 13.0 & 13.0 \\
\hline Breast irritations: none & 60.5 & 74.5 & 72.0 \\
\hline slight & 32.5 & 20.5 & 22.5 \\
\hline moderate & 7.0 & 5.0 & 5.0 \\
\hline severe & 0.0 & 0.0 & 0.5 \\
\hline Breast blisters: none & $45.0^{\mathrm{a}}$ & $24.5^{\mathrm{b}}$ & $22.5^{\mathrm{b}}$ \\
\hline slight & $48.0^{(\mathrm{a})}$ & $64.5^{(\mathrm{b})}$ & $69.0^{(\mathrm{b})}$ \\
\hline moderate & 7.0 & 11.0 & 8.5 \\
\hline Hock irritations: none & 88.0 & 85.0 & 84.0 \\
\hline slight & 12.0 & 14.0 & 15.0 \\
\hline moderate & 0.0 & 1.0 & 1.0 \\
\hline Footpad irritations: none & $97.0^{(\mathrm{ab})}$ & $99.5^{(\mathrm{a})}$ & $94.5^{(\mathrm{b})}$ \\
\hline slight & 3.0 & 0.5 & 4.0 \\
\hline moderate & 0.0 & 0.0 & 1.5 \\
\hline
\end{tabular}

${ }^{\mathrm{ab}}$ Values in a row not sharing a common superscript are significantly different $(P<0.05)$. 
338 Table 6. Processing yields of broilers receiving $80 \%$, 95\% and 100\% organic feed at 11

\begin{tabular}{llll}
\multicolumn{4}{c}{ weeks of age } \\
\hline & $80 \%$ & $95 \%$ & $100 \%$ \\
\hline Carcase (\% of live weight) & 68.7 & 70.0 & 69.0 \\
\hline Leg (\% of carcase weight) & $33.9^{(\mathrm{a})}$ & $33.8^{(\mathrm{a})}$ & $34.3^{(\mathrm{b})}$ \\
Wing (\% of carcase weight) & $11.8^{\mathrm{a}}$ & $11.7^{\mathrm{a}}$ & $12.1^{\mathrm{b}}$ \\
\hline Breast (\% of carcase weight) & 21.8 & 21.3 & 21.2 \\
\hline Back (\% of carcase weight) & 9.6 & 9.8 & 9.7
\end{tabular}

340

${ }^{\mathrm{ab}}$ Values in a row not sharing a common superscript are significantly different $(P<0.05)$.

341 (a) (b) Different superscripts between brackets indicate a tendency $(P<0.10)$. 
342 Table 7. Economic results for broilers receiving $80 \%$, 95\% and $100 \%$ organic feed $(€$ per $1000 \mathrm{~kg}$ live weight)

\begin{tabular}{lrrr}
\hline & $80 \%$ & $95 \%$ & $100 \%$ \\
\hline Day old chicken & 169 & 167 & 174 \\
Feed costs & 973 & 1000 & 1049 \\
Other variable costs & 113 & 112 & 116 \\
Housing costs & 185 & 182 & 190 \\
Labour costs & 283 & 280 & 291 \\
Other non-variable costs & 96 & 95 & 99 \\
Total costs & 1828 & 1843 & 1927 \\
\hline
\end{tabular}


345 Figure. Percentage of broilers observed in the outdoor run for groups receiving $80 \%, 95 \%$, or $100 \%$ organic feed from 5 - 9 weeks of age.

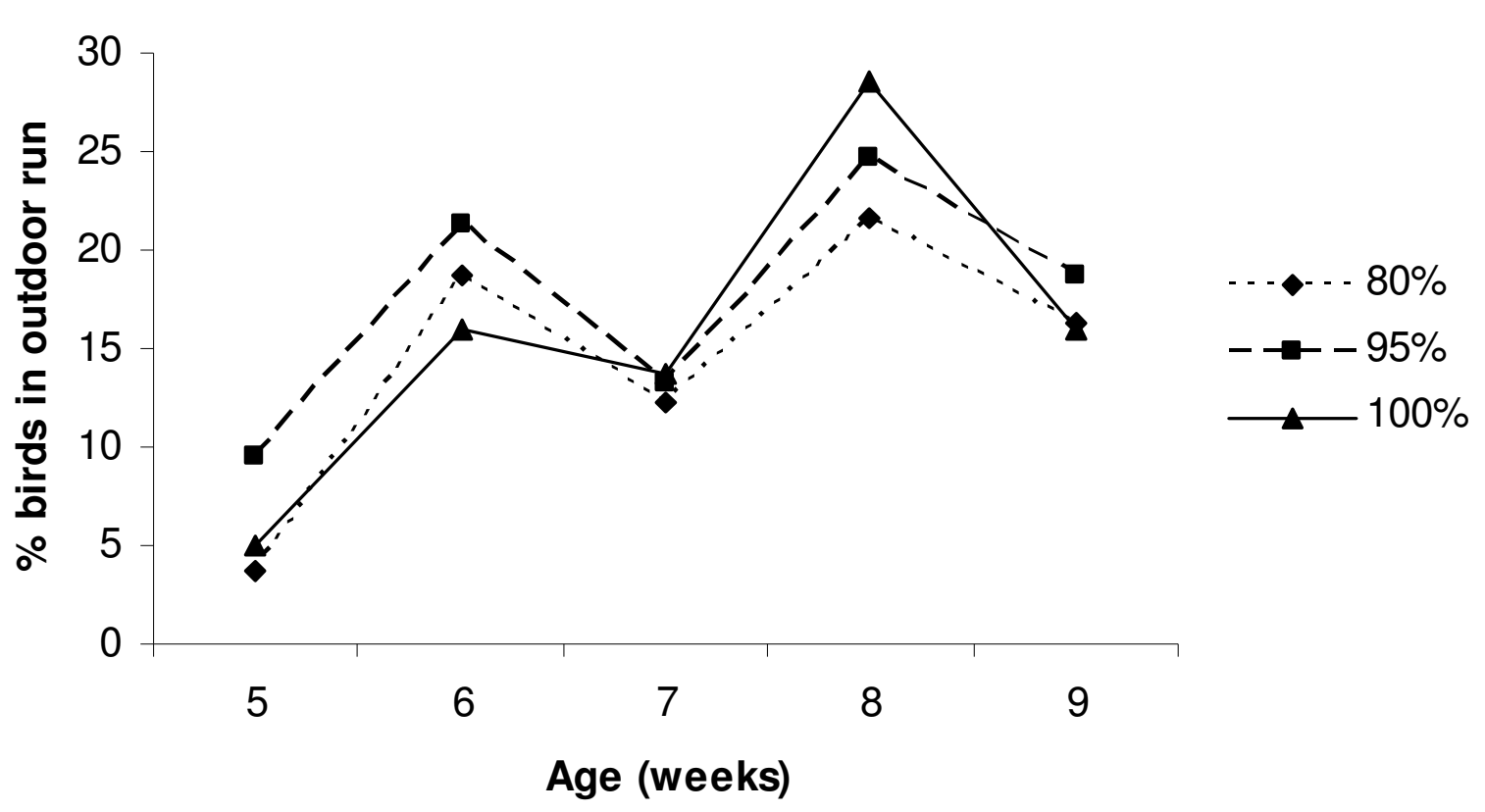

